\title{
The Structure-Activity Relationships in Coronatine Analogs and Amino Compounds Derived from (+)-Coronafacic Acid
}

\author{
Kunio Shiraishi, * Keiichi Konoma, * Hiroji Sato, * \\ Akitami Ichihara, ${ }^{*}$ Sadao Sakamura, ${ }^{*}$ Koji NishiYama** \\ and Ryutaro SAKAI*** \\ *Department of Agricultural Chemistry, Faculty of Agriculture, \\ Hokkaido University, Sapporo 060, Japan \\ **National Institute of Agriculture Science, Tokyo, Japan \\ ***Laboratory of Environmental Botany, Obihiro University, \\ Obihiro 080, Japan
}

Received March 12, 1979

\begin{abstract}
In order to investigate the active site of coronatine, the coronatine stereoisomers and analogs were synthesized by replacing the coronamic acid moiety with other amino compounds. The hypertrophy response of potato tubers was used for the bioassay of the compounds. A carboxyl group in coronamic acid was indispensable for the induction of activity. Moreover, the configuration at $\alpha$-carbon atom in the amino acid was closely related to increase in activity. Some alkyl groups of the amino acid also concerned with the activity.
\end{abstract}

A number of phytotoxic compounds produced by microbes have been isolated." In many cases phytotoxins contain amino acid units in the molecule. Some of them are novel compounds and are assumed to play an important role in induction of phytotoxic reactions. But the studies of structure-activity relationships have been scant for these compounds. Especially in regard to bacterial phytotoxins, there has so far been only one example, phaseolotoxin reported by Mitchel. ${ }^{2}$ Coronatine (1), whose isolation and structural determination were made by the present authors, ${ }^{3)}$ also contains a unique amino acid unit containing a cyclopropane ring.

In the course of our investigation for physiological activity-structure relationships, this paper deals with contribution of an amino acid moiety $[(+)$-coronamic acid (2)] in 1 to the induction of physiological activity. It was reported that 1 has several interesting physiological activities' to some plants, e.g. hypertrophy of potato cells, inhibition of root elongation for wheat etc. In this study the hypertrophy response of potato cells was used as a bioassay because of its simplicity.

\section{Preparation of the coronatine analogs}

Stereoisomeric coronatines were prepared by the condensation of the stereoisomers of 2 with natural $(+)$-coronafacic acid (3). Three stereoisomers (one enantiomer and two diastereomers) of $\mathbf{2}$ were obtained by the stereoselective syntheses and subsequent optical resolutions. ${ }^{5,6)}$ The stereochemistries of four amino acids [2, (-)-coronamic acid, (+)-allocoronamic acid and (-)-allocoronamic acid] have been unequivocally established by X-ray analysis and an enzymatic method." Coronatine isomer-I (4) had already been synthesized from (-)-coronamic acid (enantiomer of 2) and $3 .^{5}$ Coronatine isomer-II (5) and coronatine isomer-III (6) were synthesized by the condensation of $(+)$-allocoronamic acid and (-)-allocoronamic acid with $\mathbf{3}$, respectively. Both $(+)$-allocoronamic acid and ( - )-allocoronamic acid were prepared previously. $\left.{ }^{6}\right)$ All the coronatine stereoisomers thus obtained were powders which were chromatographically pure. Mass spectra of these compounds are very similar to that of $1 .{ }^{3)}$ The IR and NMR spectra of the stereoisomers $(\mathbf{4}, 5$ and $\mathbf{6})$ are slightly different from 1 and the data are given in experimental section. 




FIG. 1. Structures of Coronatine, Its Stereoisomers and Analogs.
The coronatine analogs were prepared by replacing the coronamic acid part with other amino acids: 1-aminocyclopropane-1-carboxylic acid, L-isoleucine (L-Ile), D-isoleucine (DIle), glycine (Gly), $\beta$-alanine ( $\beta$-Ala) and $\gamma$ aminobutyric acid (GABA). The amino acids were condensed with 3 by the same method as for coronatine stereoisomers to yield the analogs. The analogs thus synthesized are shown in Fig. 1. In the case of L-Ile and $\beta$-Ala, both the condensates ( $N$-coronafacoylD-isoleucine and $N$-coronafacoyl- $\beta$-alanine) were obtained in a crystalline form. But other products purified by column chromatography and by preparative TLC were not crystallizable. Physicochemical properties for these analogs are given in experimental section. The stereochemistries at ring junction in indanone moiety of all condensates including the coronatine stereoisomers was confirmed to be cis-configuration by the presence of the signals due to the deshielded $\alpha$-keto

Table I. Hypertrophy Response of Potato Tuber Disks to Coronatine AND THE RELATEd COMPOUNDS

\begin{tabular}{|c|c|c|c|c|c|c|c|}
\hline \multirow{2}{*}{\multicolumn{2}{|c|}{ Compounds }} & \multicolumn{6}{|c|}{ Concentration of the compounds (M) } \\
\hline & & $10^{-2}$ & $10^{-3}$ & $10^{-4}$ & $10^{-5}$ & $10^{-8}$ & $10^{-7}$ \\
\hline \multicolumn{2}{|c|}{ Coronatine (1) } & 1 & + & + & + & \pm & \pm \\
\hline \multicolumn{2}{|c|}{ Coronatine isomer-I (4) } & + & + & + & \pm & - & - \\
\hline \multicolumn{2}{|c|}{ Coronatine isomer-II (5) } & + & \pm & - & - & - & - \\
\hline \multicolumn{2}{|c|}{ Coronatine isomer-III (6) } & + & + & \pm & - & - & - \\
\hline \multicolumn{8}{|c|}{ Coronatine isomer from } \\
\hline \multicolumn{2}{|c|}{$( \pm)$-coronamic acid } & + & + & + & \pm & - & - \\
\hline \multicolumn{2}{|c|}{ Coronatine methyl ester (14) } & + & \pm & - & - & - & - \\
\hline \multicolumn{2}{|c|}{ cis-Coronafacic acid (3) } & - & - & - & - & - & - \\
\hline \multicolumn{2}{|c|}{$(+)$-Coronamic acid (2) } & - & - & - & - & - & - \\
\hline \multicolumn{2}{|c|}{$( \pm)-N$-Formycoronamic acid } & - & - & - & - & - & - \\
\hline \multicolumn{2}{|c|}{$\begin{array}{c}( \pm) \text {-N-Acetylcoronamic acid } \\
\text { (Substituted moieties) } \\
\text { COOH }\end{array}$} & - & - & - & - & - & - \\
\hline \multicolumn{2}{|c|}{7} & + & + & + & - & - & - \\
\hline 8 & L-Ile & + & + & + & + & - & - \\
\hline 9 & D-Ile & + & - & - & - & - & - \\
\hline & Gly & \pm & - & - & - & - & - \\
\hline & $\beta$-Ala & \pm & - & - & - & - & - \\
\hline & GABA & + & \pm & - & - & - & - \\
\hline & Methyl amine & - & - & - & - & - & - \\
\hline
\end{tabular}

In each concentration five disks were used.

+ , four to all disks showed the activity; \pm , one to three disks showed the activity; - , no disk had the activity. 
methine at $\delta 3.2 \sim 3.3$ in the NMR spectra. ${ }^{5}$

Physiological activities of the coronatine analogs

The activity found for 1 and its stereoisomers (4, 5 and 6) is summarized in Table I. Acetone solutions of various concentrations $\left(10^{-2}\right.$ to $10^{-7} \mathrm{M}$ ) were prepared two times and each solution was bioassayed twice or more using five potato disks for each run. The observed values were averaged and tabulated. The hypertrophy response was proportional to the concentration of the compounds. The response was detected qualitatively with good reproducibility. Coronatine (1) showed the highest activity among the four stereoisomers $1,4,5$ and 6 , and was active at $10^{-6} \sim 10^{-7} \mathrm{M}$. The activity of these compounds was in the order; 1, 4, 6, and 5. The results indicate that the contribution of coronamic acids to the induction of activity was more substantial than that of allocoronamic acids, and of enantiomeric pairs, (+)-coronamic acid (2) and (-)-allocoronamic acid were more effective than the counterparts. It is assumed that the configurations of $\alpha$-carbon atom in amino acid moiety would be concerned with the induction of activity.

The results of the activity test for other analogs are also summarized in Table I. The same extent of activities found for 1- $N$-coronafacoylaminocyclopropane-1-carboxylic acid (7) and $N$-coronafacoyl-L-isoleucine (8) suggests that the cyclopropane ring in coronatine is not indispensable for the activity. The configuration at $\alpha$-carbon atom in the amino acid moiety proved to be important by comparison of $N$ coronafacoyl-L-isoleucine (8) and $N$-coronafacoyl-D-isoleucine (9). Namely, the amino acids having $S$-configuration at $\alpha$-carbon atom [e.g. $(+)$-coronamic acid (2), (-)-allocoronamic acid and L-Ile] indicated high physiological activity as compared with the R-enantiomers. When the simplest $\alpha$-amino acid, glycine was incorporated as amino acid moiety, $N$-coronafacoylglycine (10) exhibited a weak activity at $10^{-2} \mathrm{M}$. This implies that alkyl group in the amino acid is indispensable for the enhancement of activity.
The importance of carboxyl group in $\mathbf{1}$ for developing the activity was proved by two compounds, $N$-methylcoronafacamide (13 and coronatine methyl ester (14). $N$-methylcoronafacamide lacking carboxyl group in the molecule was found to be inactive. Coronatine methyl ester (14) obtained by treatment of 1 with diazomethane was $10^{-4}$ times as active as 1 , which might be due to the contamination of a trace of 1 arising from partial hydrolysis of 14.

The effect of location of carboxyl group on the activity was investigated by using two amino acids, $\beta$-Ala and GABA. $N$-Coronafacoyl- $\gamma$-aminobutyric acid (12) derived from GABA showed a little higher activity $\left(10^{-3} \mathrm{M}\right)$ than $N$-coronafacoyl- $\beta$-alanine (11) derived from $\beta$-Ala $\left(10^{-2} \mathrm{M}\right)$.

In addition, 2, 3, ( \pm )- $N$-formylcoronamic acid and $( \pm)$ - $N$-acetylcoronamic acid were bioassayed according to the same procedure.

Both compounds, 2 and 3, and $N$-acyl derivatives of 2 gave the negative results. The coexistance of $\mathbf{2}$ and $\mathbf{3}$ also indicated no activity.

In conclusion, presence of carboxyl group is indispensable for the hypertrophy induction of potato cells and moreover, for enhancement of the activity, existence of alkyl groups and the configuration at $\alpha$-carbon atom in amino acid are very important. Since $N$-acyl derivatives of 2 were inactive, it was suggested that other functional groups for inducing the activity would be concerned with coronafacic acid moiety.

\section{EXPERIMENTAL}

NMR spectra were measured with a Hitachi model R-22 high resolution. NMR spectrometer $(90 \mathrm{MHz})$, with deuterioacetone or deuteriochloroform as solvent using tetramethylsilane as an internal standard. Mass spectra were obtained with a model Hitachi RMS-4 mass spectrometer and a JEOL JMS-D300 mass spectrometer. IR spectra were recorded on a 285 type Hitachi grating IR spectrophotometer. Optical rotation were measured with a PO-B type Hitachi polarimeter. Melting points were determined on a Yanaco micro melting point apparatus MP-30 and were uncorrected. 
Bioassay of synthesized compounds. Two microliters of acetone solution containing the sample was dropped to a filter paper (TOYO No. 4) with $5 \mathrm{~mm}$ in diameter and the paper was dried at room temperature. The filter paper was put on a potato disk $(10 \mathrm{~mm}$ in diameter and $5 \mathrm{~mm}$ in height) and was moistened with a small amount of deionized water. The potato disks with the filter paper were kept in a petri dish $(9 \mathrm{~cm}$ in diameter) containing both moistened filter paper and gause. Hypertrophy response of the sample was observed after 5 days at $23^{\circ} \mathrm{C}$.

Preparation of the compounds. Preparation of 4 was described in our previous paper. ${ }^{6)}$

Synthesis of 5: Acid chloride of 2 was obtained by refluxing $2(30 \mathrm{mg})$ and thionyl chloride $(25 \mu 1)$ in dried benzene $(0.5 \mathrm{ml})$ in $1.5 \mathrm{hr}$ followed by evaporation of thionyl chloride and benzene in vacuo. Crude acid chloride $(\mathrm{ca} .32 \mathrm{mg})$ was used for the next reaction. After $18.6 \mathrm{mg}$ of $(+)$-allocoronamic acid and magnesium oxide $(8.6 \mathrm{mg})$ were dissolved in $0.4 \mathrm{ml}$ of cold water, the acid chloride dissolved in about $1 \mathrm{ml}$ of dried dioxane was added and the mixture was vigorously stirred for $10 \mathrm{~min}$. The reaction mixture was acidified with $6 \mathrm{~N} \mathrm{HCl}$ and extracted three times with a small portion of ethyl acetate. The combined extracts were dried over anhydrous magnesium sulfate and concentrated in vacuo. The crude residue was purified by silicic acid column chromatography (Kieselgel 60, $1 \mathrm{~g}$ ) eluting with isopropyl ether-acetic acid $(95: 5, \mathrm{v} / \mathrm{v})$ and ethyl acetate and by preparative TLC (Wakogel G-5) using acetone-benzene $(1: 1, \mathrm{v} / \mathrm{v})$. The isomer $\mathbf{5}$ was obtained as powders after drying in vacuo in 34\% yield. Physicochemical properties for 5 are as follows: mp 92 97 ${ }^{\circ} \mathrm{C}$ (powders), $[\alpha]_{D}^{20}+53.3^{\circ}(c=0.92, \mathrm{MeOH})$, MS $m / e: 319\left(\mathrm{M}^{+}\right), 301\left(\mathrm{M}^{+}-\mathrm{H}_{2} \mathrm{O}\right), 191,128,119$, $105,91,79,77, \mathrm{IR} \underset{\nu_{\text {max }}}{\mathrm{KBr}} \mathrm{cm}^{-1}: 3350(\mathrm{NH}, \mathrm{OH}), 1720$ $(\mathrm{C}=\mathrm{O}, \mathrm{COOH}), 1635(\mathrm{C}=\mathrm{C}), 1665(\mathrm{CONH}), 1525$ (CONH), NMR $\delta^{d}{ }^{d}$ - Acetone $_{\mathrm{Me}_{4} \mathrm{SI}}: 3.28(1 \mathrm{H}, \mathrm{br} . \mathrm{s}, \mathrm{O}=\mathrm{C}-\mathrm{CH})$, $6.54(1 \mathrm{H}, \mathrm{br} . \mathrm{s},=\mathrm{H}), 7.65(1 \mathrm{H}, \mathrm{br} . \mathrm{s}, \mathrm{CONH})$.

As the compounds, $6,7,8,9,10,11$ and 12 were synthesized by exactly the same procedure as for 5 , only the yields and spectral data of these compounds are described.

Coronatine isomer-III (6): yield $15.2 \%, \mathrm{mp} 97 \sim$ $103^{\circ} \mathrm{C}$ (powders), $[\alpha]_{\mathrm{D}}^{18} 0.0^{\circ}(c=0.85, \mathrm{MeOH}), \mathrm{MS} m / e$ : $319\left(\mathrm{M}^{+}\right), 301\left(\mathrm{M}^{+}-\mathrm{H}_{2} \mathrm{O}\right), 191,128,119,105, \mathrm{IR}$ ${ }_{\max }^{\mathrm{KBr}} \mathrm{cm}^{-1}: 3350(\mathrm{NH}, \mathrm{COOH}), 1720(\mathrm{C}=\mathrm{O}, \mathrm{COOH})$, $1665(\mathrm{CONH}), 1635(\mathrm{C}=\mathrm{C}), 1520(\mathrm{CONH}), \mathrm{NMR}$ $\delta^{d}{ }_{\mathrm{He}_{4} \mathrm{Ai}}^{\text {Acetone }}: 3.28(1 \mathrm{H}$, br.s, $\mathrm{O}=\mathrm{C}-\mathrm{CH}), 6.54(1 \mathrm{H}$, br.s, $=), 7.63(1 \mathrm{H}$, br.s, $\mathrm{CONH})$. $\mathrm{H}$

1-N-Coronafacoylaminocyclopropane-1-carboxylic acid (7): Yield $43.2 \%, \mathrm{mp} 88.5 \sim 90.0^{\circ} \mathrm{C}$ (powders), $[\alpha]_{\mathrm{D}}^{15}$ $+46.2^{\circ}(c=1.32, \mathrm{MeOH})$, MS m/e: $291\left(\mathrm{M}^{+}\right), 273$
$\left(\mathrm{M}^{+}-\mathrm{H}_{2} \mathrm{O}\right), 245,191,119,86,55, \mathrm{IR} \nu_{\max }^{\mathrm{KBr}} \mathrm{cm}^{-1}: 3360$ $(\mathrm{NH}, \mathrm{COOH}), 1740(\mathrm{C}=\mathrm{O}, \mathrm{COOH}), 1660(\mathrm{CONH})$, $1625(\mathrm{C}=\mathrm{C}), 1520(\mathrm{CONH}), \mathrm{NMR} \delta^{d_{6}-\mathrm{Acetone}_{\mathrm{Me}} \mathrm{Si}}: 0.95$ (3H, t, $J=7 \mathrm{~Hz}, \mathrm{CH}_{3}$ ), 1.13, 1.45 (each $2 \mathrm{H}, \mathrm{m}$, methylenes of cyclopropane), $3.22(1 \mathrm{H}$, br.s, $\mathrm{O}=\mathrm{C}-\mathrm{CH})$, $6.50(1 \mathrm{H}, \mathrm{br} . \mathrm{s},=), \mathrm{H} .82(1 \mathrm{H}, \mathrm{br.s}, \mathrm{CONH})$.

$N$-Coronafacoyl-L-isoleucine (8); yield $36.3 \%, \mathrm{mp}$ $53 \sim 55^{\circ} \mathrm{C}$ (powders), $[\alpha]_{D}^{15}+44.0 \quad(c=2.25, \mathrm{MeOH})$, MS $m / e: 321\left(\mathrm{M}^{+}\right), 303\left(\mathrm{M}^{+}-\mathrm{H}_{2} \mathrm{O}\right), 276\left(\mathrm{M}^{+}-\mathrm{COOH}\right)$, 265, 209, 191, 190, 86, IR $\nu_{\max }^{\mathrm{KB}} \mathrm{cm}^{-1}: 3360(\mathrm{NH}$, $\mathrm{COOH}), 1740(\mathrm{C}=\mathrm{O}, \mathrm{COOH}), 1620(\mathrm{C}=\mathrm{C}), 1660$, $1525(\mathrm{COHN}), \mathrm{NMR} \delta^{\alpha_{\theta}{ }_{\mathrm{Me}_{4} \mathrm{Ai}}^{\mathrm{Aceton}}}: 0.97(9 \mathrm{H}, \mathrm{m}, 3 \times$ $\left.\mathrm{CH}_{3}\right), 3.22(1 \mathrm{H}$, br.s, $\mathrm{O}=\mathrm{C}-\mathrm{CH}), 4.55(1 \mathrm{H}$, quartet, $J=8 \mathrm{~Hz}, 5 \mathrm{~Hz}, \mathrm{CH}-\mathrm{N}), 6.53(1 \mathrm{H}$, br.s, $=\underset{\mathrm{H}}{\mathrm{H}}), 7.12(1 \mathrm{H}$, br.s, CONH).

$N$-Coronafacoyl-D-isoleucine (9): yield $17.0 \%, \mathrm{mp}$ $139.0 \sim 140.0^{\circ} \mathrm{C} \quad$ (crystals), $[\alpha]_{D}^{15}+20.7^{\circ} \quad(c=0.58$, $\mathrm{MeOH}), \mathrm{MS} m / e: 321\left(\mathrm{M}^{+}\right), 303\left(\mathrm{M}^{+}-\mathrm{H}_{2} \mathrm{O}\right), 276\left(\mathrm{M}^{+}-\right.$ COOH), 265, 191, 190, 119, IR $\nu_{\max }^{\mathrm{KBr}} \mathrm{cm}^{-1}: 3375$ (NH, I $\mathrm{COOH}), 1740(\mathrm{C}=\mathrm{O}), 1730(\mathrm{COOH}), 1655,1555$ $(\mathrm{CONH}), 1605(\mathrm{C}=\mathrm{C}), \mathrm{NMR} \delta^{d} 6_{\mathrm{Me}_{4} \mathrm{Ai}}^{-\mathrm{Acetone}}: 0.98(9 \mathrm{H}, 7$ $\mathrm{m}, 3 \times \mathrm{CH}_{3}$ ), 3.22 (1H, br.s, $\left.\mathrm{O}=\mathrm{C}-\mathrm{CH}\right), 4.78(\mathrm{IH}$, quartet, $J=10 \mathrm{~Hz}, 6 \mathrm{~Hz}, \mathrm{CH}-\mathrm{N}), 6.53(1 \mathrm{H}$, br.s, $=)$, 7.03 (1H, br.s, CONH).

$N$-Coronafacoylglycine (10): yield $63 \%, \mathrm{mp} 65 \sim$ $70^{\circ} \mathrm{C}$ (powders), $[\alpha]_{D}^{26}+23.1^{\circ}(c=2.42, \mathrm{MeOH}), \mathrm{MS} m / e$ : $\left.265\left(\mathrm{M}^{+}\right), 247\left(\mathrm{M}^{+}-\mathrm{H}_{2} \mathrm{O}\right), 191,190,119,105,91,74\right]$ $\left(\mathrm{C}_{2} \mathrm{H}_{4} \mathrm{O}_{2} \mathrm{~N}\right), \mathrm{IR} \nu_{\max }^{\mathrm{KBr}} \mathrm{cm}^{-1}: 3400(\mathrm{NH}, \mathrm{COOH}), 1740$ $(\mathrm{C}=\mathrm{O}, \mathrm{COOH}), 1660,1540(\mathrm{CONH}), 1630(\mathrm{C}=\mathrm{C}))$ NMR $\delta^{d}{ }_{\mathrm{Me}_{4} \mathrm{si}}^{-\mathrm{Acetone}^{2}}: 0.97\left(3 \mathrm{H}, \mathrm{t}, J=7 \mathrm{~Hz}, \mathrm{CH}_{3}\right), 3.20(1 \mathrm{H}$, br.s, $\mathrm{O}=\mathrm{C}-\mathrm{CH}), 4.00\left(2 \mathrm{H}, \mathrm{t}, J=4 \mathrm{~Hz}, \mathrm{CH}_{2}-\mathrm{N}\right), 6.55$ $(1 \mathrm{H}$, br.s, $=), 7.55(1 \mathrm{H}$, br.s, $\mathrm{NH})$. $\mathrm{H}$

$N$-Coronafacoyl-p-alanine (11): yield $44.8 \%, \mathrm{mp}$ $161.0 \sim 162.0^{\circ} \mathrm{C}$ (crystals), $[\alpha]_{D}^{18}+53.3^{\circ}(c=0.92, \mathrm{MeOH})$, MS m/e: $279\left(\mathrm{M}^{+}\right), 261\left(\mathrm{M}^{+}-\mathrm{H}_{2} \mathrm{O}\right), 191,190,133,119$, 105, 91, IR $\nu_{\max }^{\mathrm{KBr}} \mathrm{cm}^{-1} ; 3400(\mathrm{NH}, \mathrm{COOH}), 1730$ $(\mathrm{C}=\mathrm{O}, \mathrm{COOH}), 1610(\mathrm{C}=\mathrm{C}), 1655,1550(\mathrm{CONH})$, NMR $\delta^{d_{6}-{ }_{\mathrm{Me}_{4} \mathrm{Si}}^{\mathrm{Acetone}}}: 1.00\left(3 \mathrm{H}, \mathrm{t}, J=7 \mathrm{~Hz}, \mathrm{CH}_{3}\right), 2.62(2 \mathrm{H}$, t, $\left.J=7 \mathrm{~Hz}, \mathrm{CH}_{2}-\mathrm{COO}\right), 3.22(1 \mathrm{H}$, br.s, $\mathrm{O}=\mathrm{C}-\mathrm{CH})$, $3.57\left(2 \mathrm{H}\right.$, quartet, $\left.J=7 \mathrm{~Hz}, \mathrm{CH}_{2}-\mathrm{N}\right), 6.47(1 \mathrm{H}$, br.s, $=), 7.38(1 \mathrm{H}$, br.s, $\mathrm{NH})$. $\mathrm{H}$

$N$-Coronafacoyl- $\gamma$-amino-nibutyric acid (12): yield $23 \%,[\alpha]_{\mathrm{D}}^{17}+66.7^{\circ}(c=0.54, \mathrm{MeOH}), \mathrm{MS} m / e: 293\left(\mathrm{M}^{+}\right)$, $275\left(\mathrm{M}^{+}-\mathrm{H}_{2} \mathrm{O}\right), 191,190,133,105,91, \mathrm{IR} \nu_{\max }^{\mathrm{film}} \mathrm{cm}^{-1}$; $3370(\mathrm{NH}, \mathrm{COOH}), 1740(\mathrm{C}=\mathrm{O}, \mathrm{COOH}), 1615(\mathrm{C}=\mathrm{C})$, $1660,1540(\mathrm{CONH}), \mathrm{NMR} \delta^{d_{6}-\mathrm{Acetone}_{\mathrm{Me}} \mathrm{Mi}}: 0.97(3 \mathrm{H}, \mathrm{t}$, $\left.J=7 \mathrm{~Hz}, \mathrm{CH}_{3}\right), 2.38\left(2 \mathrm{H}, \mathrm{m}, \mathrm{CH}_{2}-\mathrm{COO}\right), 3.20(1 \mathrm{H}$, br.s, $\mathrm{O}=\mathrm{C}-\mathrm{CH}$ ), $3.38\left(2 \mathrm{H}\right.$, quartet, $J=7 \mathrm{~Hz}, \mathrm{CH}_{2}-\mathrm{N}$ ), $6.59(1 \mathrm{H}$, br.s, $=\underset{\mathrm{H}}{\mathrm{H}} \mathrm{f} .38(1 \mathrm{H}$, br.s, CONH$)$. 
$N$-Methylcoronafacamide (13): Coronafacoyl chloride prepared from $20 \mathrm{mg}$ of 3 with thionyl chloride was added to $0.2 \mathrm{ml}$ of cold water containing an excess of methyl amine. The reaction mixture was stirred for $10 \mathrm{~min}$ at room temperature and was extracted three times with ethyl ether. After the extracts were dried over anhydrous calcium chloride, the solvent was removed in vacuo. Crude compound was purified by silicic acid (Kieselgel 60) chromatography to give 13, yield $56.5 \%,[\alpha]_{\mathfrak{b}}^{26}+72.0^{\circ}(c=1.0, \mathrm{MeOH})$, MS $m / e$ : $221\left(\mathrm{M}^{+}\right), 206\left(\mathrm{M}^{+}-\mathrm{CH}_{8}\right), 191,164,91,89,30\left(\mathrm{CH}_{3} \mathrm{NH}\right)$, IR $\nu_{\max }^{\text {film }} \mathrm{cm}^{-1}: 3350(\mathrm{NH}), 1740(\mathrm{C}=\mathrm{O}), 1660,1540$

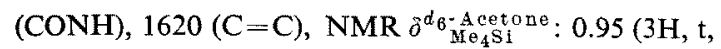
$\left.J=7 \mathrm{~Hz}, \mathrm{CH}_{3}\right), 2.75\left(3 \mathrm{H}, \mathrm{d}, J=4.5 \mathrm{~Hz}, \mathrm{~N}-\mathrm{CH}_{3}\right), 3.20$ $(1 \mathrm{H}$, br.s, $\mathrm{O}=\mathrm{C}-\mathrm{CH}), 6.42(1 \mathrm{H}$, br.s, $=\underset{\mathrm{H}}{=}), 2.25(1 \mathrm{H}$, br.s, CONH).

Coronatine methyl ester (14): An excess of ethereal diazomethane dried over $\mathrm{KOH}$ was added to $8 \mathrm{mg}$ of 1 dissolved in a small portion of ethyl acetate. The reaction mixture was kept at room temperature, allowed to dry up and extracted with a small portion of ether followed by filtration. The oil obtained by concentration of the filtrate in vacuo was homogeneous on TLC. Yield $95.5 \%$, MS m/e: $333\left(\mathrm{M}^{+}\right), 301\left(\mathrm{M}^{+}-\right.$ $\mathrm{MeOH}), 191,142,119, \mathrm{IR} 2_{\max }^{\mathrm{fllm}} \mathrm{cm}^{-1}: 3320$ !(NH), $\left(\mathrm{C}=\mathrm{O}, \mathrm{COOCH}_{8}\right), 1625(\mathrm{C}=\mathrm{C}), 1660,1515(\mathrm{CONH})$, NMR $\delta{ }_{\mathrm{Mesi}}^{\mathrm{CDCl}}: 1.00\left(6 \mathrm{H}, \mathrm{t}, J=7 \mathrm{~Hz}, 2 \times \mathrm{CH}_{3}\right), 3.20$ $(1 \mathrm{H}$, br.s, $\mathrm{O}=\mathrm{C}-\mathrm{CH}), 3.74\left(3 \mathrm{H}, \mathrm{s}, \mathrm{OCH}_{3}\right), 6.30(1 \mathrm{H}$, br.s, $=\underset{H}{H}$.

Acknowledgment. The authors thank Dr. Honma, Department of Agricultural Chemistry, Hokkaido University, for supplying a sample of 1-aminocyclopropane1-carboxylic acid.

\section{REFERENCES}

1) G. A. Strobel, Ann. Rev. Plant Physiol., 25, 541 (1974); G. A. Strobel "Biochemical Aspects of Plant-Parasite Relationships," ed. by J. Friend and D. R. Threlfall, Academic Press, New York, 1976, p. 135.

2) R. E. Mitchel Phytochem., 15, 1941 (1976).

3) A. Ichihara, K. Shiraishi, H. Sato, S. Sakamura, K. Nishiyama, R. Sakai, A. Furusaki and T. Matsumoto, J. Am. Chem. Soc., 99, 636 (1977).

4) R.Sakai, Abstracts of Paper, 11th Pesticide Science Symposium, Japan, Sapporo, November, 1978, p. 21.

5) A. Ichihara, K. Shiraishi, S. Sakamura, K. Nishiyama and R. Sakai, Tetrahedron Lett., 1977, 629.

6) K. Shiraishi, A. Ichihara and S. Sakamura, Agric. Biol. Chem., 41, 2497 (1977).

7) A. Ichihara, K. Shiraishi, S. Sakamura, A. Furusaki, N. Hashiba and T. Matsumoto, Tetrahedron Lett., 1979, 365; cf. ref. 6. 